\title{
The contribution of David H. Bayley, policing research pioneer
}

Richard Heslop, Police Sergeant, West Yorkshire Police, UK, \& Visiting Scholar, John Jay College of Criminal Justice U.S.A

\begin{abstract}
This essay chronicles the contribution of leading international policing scholar - David H. Bayley. Although he may first and foremost be regarded as a political scientist, it is in the field of international policing studies, where he became preeminent. The article makes the case that Professor Bayley is a policing_research pioneer_and it draws upon interviews and correspondence with him, and those who know him, as well as a review of his extensive body of scholarship spanning seven decades.
\end{abstract}

Key words: David H. Bayley; comparative policing; democratic policing; politics and policing.

A global perspective transforms the study of the police from an applied, technical speciality into an undertaking that enables us to understand more fully essential elements of government and the human condition (Bayley, 1999:11).

\section{Introduction}

In September1945, Senator J. William Fulbright introduced a bill in the U.S Congress that called for the use of_proceeds from the sale of surplus American war assets to fund international exchange between the U.S.A. and other countries. With the crucial timing of the end of the Second World War and with the pressing establishment of the United Nations, the initiative aimed to promote international goodwill through educational exchange. As President, Truman asserted, 'if we do not want to die together in war, we must learn to live together in peace'. ${ }^{1}$ In 1946, Truman signed the bill into law and Congress created the Fulbright Program, which was to become one of the most prestigious educational exchange programs in the world.

Nine years after its creation, a young American scholar was awarded a prestigious Fulbright Fellowship to read Philosophy, Politics and Economics (PPE) at Oxford University, England. Although this scholarship cannot have been cheap, dollar for dollar, in relation to the Fulbright's long-term mission to increase the mutual understanding between the people of the | United States and other countries,_this particular grant_comprised some of the best bucks the Awards Committee ever spent. For it helped launch the career of an academic who, after proceeding to gain a $\mathrm{PhD}$ in political science from Princeton University, would go on to become America's principal, most respected and longest serving_policing expert at-large and the world's preeminent scholar of international policing studies. 
Whilst he may first and foremost be regarded as a political scientist it is in the field of international policing studies where he made his name. In an era when some of his contemporaries were grappling with the challenges of conducting empirical research into the police in their own countries, he was in foreign fields carrying out pioneering studies of the | Indian and Japanese police._Subsequently, his original research and consultation projects for the U.S. Government, United Nations and numerous foreign law enforcement agencies would take him around the world. He is the author of 13 books, countless academic_journal articles and scholarly monographs, and numerous government-level sponsored research reports.

Although he is empirical and has maintained an interest in 'what works' in policing at the tactical level, he has not spent his career advising the police about the most effective way to deploy their_patrol cars. Rather, in an academic career spanning seven decades he has used his time wisely to engage with the important macro-level topics and issues in policing studies. These topics include: the balance between maintaining order and freedoms; the relationship between politics and policing; police and society relations; minorities and policing; human rights and the concept of democratic policing; and police accountability and reform.

In addition, along with a_handful of other scholars, he was at the forefront of drawing our field's attention to developments leading to the 'end of the monopoly' of the public police and in mapping the contours of the 'multilateralized' (Bayley \& Shearing 2001: 15) (or pluralised) system of security provision which has emerged on a global scale.

His latest published book, The Police in War (2010), co-authored with Robert M. Perito, attends to another central concern in his scholarship: the role of the police in zones of conflict. To revisit President Truman's laudable aim, human-kind has unfortunately not yet learned to live together in peace and too many people continue to die in wars.

Thankfully then, at the age of 82 , this pioneering policing scholar remains at the top of his game. And, when he is not boarding a plane to provide advice to a foreign police or government leader, he can usually be found in his office at the State University New York at Albany. Here, surrounded by a lifetime's collection of gifts of international police memorabilia, sufficient to make him a small fortune should he ever choose to auction them on eBay, he will be hard at work on his latest publication. He has been at Albany for 30 years, currently holding the position of Distinguished Professor (Emeritus) in the School of Criminal Justice. But much 
more: in America to be sure and indeed on the world stage, David H. Bayley is the de facto Dean of international policing studies.

\section{Early life and studies}

David Hume Bayley was born in New York, U.S.A. in March 1933. His father was a philosophy professor, who had written his doctoral dissertation on the philosopher David Hume. David was raised in an intellectual household in which learning was encouraged. As a child he was | fascinated by the world beyond the United States and he had_National Geographic international maps all over his bedroom walls.

It is instructive to compare David's developing curiosity with the wider world with the outlook of many of his fellow_Americans' at that time. As the U.S. State Department acknowledges, 'during the 1930s, the combination of the Great Depression and the memory of tragic losses in World War I contributed to pushing American public opinion and policy towards isolationism'. ${ }^{2}$ Isolationists held that America was different from other societies and they advocated non-involvement in European and Asian conflicts. Although even the outbreak of war in Europe in 1939 did not defuse this popular sentiment, the events which took place in Hawaii | on 7 December 1941changed everything._On that day David, who was only eight at the time, was in his room listening to music on the radio, whilst his parents were in another part of their home. However, the wireless broadcast was interrupted with the incredible breaking news that the Japanese Imperial Navy had conducted a surprise military attack on the U.S. naval base at Pearl

| Harbour. Demonstrating an early grasp of global affairs that would later serve him well,_David immediately went to tell his parents: 'I think something important has just happened'. ${ }^{3}$ The attack led directly to America's entry into World War II_and ended domestic support for noninterventionism. The developments resulted in a huge influx of volunteers into U.S. Armed Forces, including David's father who enlisted_in the Navy.

Mercifully, David's father survived the war and following its conclusion he took a position as a professor at Denison University. At school David had shown an interest and aptitude in the natural sciences and when he enrolled as an undergraduate student at Denison in 1951 he began as a physics and math major. As David explained, 'my work bears traces that empiricism and science is the way to learn and whilst I am still interested in physics I realised that I wanted to deal with moral issues'. David graduated in 1955 with a B.A degree in philosophy. 


\section{Fulbright Scholar}

In that same year, 1955, David travelled to England to study as a Fulbright Scholar at the University of Oxford. Being at Oxford was 'like coming up for air' for the young scholar and he thrived under the one-to-one tutorial system and associated pedagogical approaches which operated at that time. As David explained:

I think the British have it right, because it's a tutorial system, not a lecture system as we have in most schools in the U.S.A. Don't get me wrong, the American education system produces some very smart people, but in my view we keep our students locked into other peoples syllabuses for too long and we don't force them early enough to think for themselves about the big questions.

David spent two years at Oxford and he graduated in 1957 with an M.A. degree in PPE. He returned to America and with a growing interest in comparative politics he_commenced a $\mathrm{PhD}$ in political science at Princeton University. As David (under) stated, 'Denison, Oxford, then Princeton, it wasn't a bad start'.

\section{Political Scientist}

The phrase 'may you live in interesting times' is an English expression purporting to be a translation of an ancient Chinese curse. In retrospect, it may be difficult to pinpoint a more interesting period to be an up-and-coming_and morally principled political scientist than the late 1950s. Although World War II had ended over a decade ago, the Cold War rivalry between the U.S.A and USSR was gathering momentum and running parallel, anti-colonial movements were on the rise in the colonies of the European nations. When David arrived at Princeton in 1957 the British Empire was 'coming apart' and it was unclear how_events would play out in some of the former colonies._David became interested in the newly independent countries and more specifically, how they were dealing with the central issue of order maintenance. For his $\mathrm{PhD}$ research he chose to focus on India, one of the first states to be granted independence (from Britain in 1947) following the end of the Second World War. In his doctoral thesis (completed 1961) he examined India's policy on preventative detention, which was one of the most contentious approaches to maintaining order in the nascent state at that time. A year later, Preventative Detention in India was published in a revised form in a book (Bayley, 1962), and his second related book Public Liberties in the New States_(Bayley, 1964)_shortly followed. 


\section{A passage to India}

In 1960 David became an Assistant Professor at the University of Wisconsin, Department of

| Political Science,_before moving in 1961 to the University of Denver, Graduate School of International Studies. By 1963 with one published book on India under his belt and another in the pipeline, he was appointed as Senior Research Fellow of the American Institute of Indian Studies.-The Fellowship came with a grant which would enable him to spend a year conducting field research in that country.

At this point we shall pause the chronological narrative to consider again the role which serendipity has played in the career trajectories of some of the world's leading policing scholars. Consider, for example, Robert Reiner's 'chance encounter with Jerome Skolnick's Justice Without Trial_(1966) that set him on the path of studying the sociology of policing' (Bowling \& Sheptycki, 2014:4). Also, Simon Holdaway's comments that, he 'never ever tried to plan out [his] career', rather he 'had some really good breaks' (Heslop, 2012:532).

| In similar vein, via his proposed_research project in India, David 'stumbled into policing'. In fact, David had originally intended to explore the causes of communal violence in India from the perspective of the 'radicals'. First, however, he had to obtain approval for the project from the Indian Government in New Deli. Upon arrival in India David met with the Permanent Secretary in the Ministry of Home Affairs to whom he explained his plans. Whilst the top civil servant listened politely, he told David that he could not allow his research to proceed, as he was afraid that David might 'rake over the ashes' and inflame the delicate situation in the newly independent state. David had to return to his hotel to rethink his plans and then he came up with 'a really brilliant idea'. Rather than focussing on the perpetrators of the violence he decided to explore how the Indian Government and its frontline agencies were_maintaining_order and specifically he would now seek approval to research the police. He duly returned to the Ministry and this time received approval for the project to proceed.

| David_spent a year in India and his book based on the research, The Police and Political Development in India was published in 1969. Looking back on this pioneering research project and book some 45 years later David explained how fortunate he had been with the way things had turned out: 
I am convinced now that if I had conducted the research the way I had originally intended, the book would have been quite dull and no one would have read it. But I was let loose and I was the first American to be given access to the police hierarchy in India.

As the title of the book suggests, this was not a narrowly focused, public administration oriented study of police organisation, typical of the approach of some early American policing scholars. But neither can it be placed in the same stable as the_ethnographic based accounts of the production of street policing, which, grounded in the disciplines of sociology and anthropology, were emerging in American-Anglo policing scholarship (e.g. Banton, 1964; Skolnick, 1966). Rather,_David's perspective in his book is 'that of a political scientist' (Bayley, 1969: 3) and in it he engages with some of the important macro-level issues and relationships concerning politics, policing and society which had been neglected by other scholars. As he wrote:

Other groups in society - such as the military, civil service, students or interest groups have been studied with a view to assessing their role in political life. The police, despite their ubiquity and identification with government, have curiously been neglected (Bayley, 1969: 3).

Whilst most sociologists and criminologists before the 1960s_might be forgiven for being slow to grasp the importance of the police as a target for systematic research and theorising, the political scientists may not. After all, the disciplines of sociology and criminology have many and varied concerns, whereas the study of politics is fundamentally the study of power_and concepts such as:-_the state, legitimacy_and force_figure centrally in the political scientists claim to expertise. In short, David saw_what his colleagues had missed: the central and reciprocal Formatted: Font: $12 \mathrm{pt}$, relationship between politics and the police. To quote a phrase which David used in his 1969 book, and which he reiterates in a number of his subsequent publications, '...police and government [can] no more be separated than knife and knife edge' (Bayley, 1969:11).

From our contemporary vantage point we may now regard it as axiomatic that a county's | system of policing is shaped by_politics and society_and to be fair by 1969 some scholars in the disciplines of sociology and criminology had no doubt arrived at the same conclusion. As a political scientist, however, David's key insight was to grasp the other side of the equation, which he explored masterfully_in his 1969 book. In the book he shows that the public police, by virtue of their unique position within state and society, can and do exert substantial influence upon the nature of a political system. 
Whilst The Police and Political Development in India was a single case study of an emerging democracy it was clear that David's thesis concerning the influence of the police upon political life had wider international applicability and he would subsequently_demonstrate this in some of his comparative policing works (e.g. Bayley, 1975, 1985). Anticipating further ahead, I would also contend that equipped with our knowledge of his background and early scholarship and, through a careful reading of his book on India we can now start to detect the_early traces of a worldview that David was developing. This intellectual project,_which brings together key themes concerning: the role of the police in democracies -both emerging and established, human rights and the concept of democratic policing - would be explored and expanded in major publications such as:- Police for the Future (1994), Changing the Guard (2006) and Police in War (2010). Suffice it for now to say, that whilst publications such as Changing the Guard (Bayley, 2006) and its forerunner, Democratizing the Police Abroad_(Bayley, 2001) can be treated as_'instruction manuals' by policy makers_involved in implementing democratic reforms of the police abroad, his perspective is grounded in his deeper level appreciation of the formative | and normative roles that the police_play_within political systems and society.

\section{Policing and minorities}

By the time that David had completed his Indian research it may have seemed to some as if things were also coming apart in his own country._Amidst the geopolitical backdrop of America fighting an unpopular war in Vietnam and with the rise of_civil rights movements demanding an end to unfair treatment of women and black citizens, civil protest and unrest broke out in many U.S. cities. Consequently, 'a new issue known as law and order emerged at the forefront of national politics' (Flamm, 2007:3), and relations between minorities and the police became one of the most pressing concerns in American criminal justice research. Again, Bayley was ahead | of the curve._As in 1969 he had another book published - Minorities and the Police: Confrontation in America - which he co-authored with Harold Mendelsohn (Bayley \& Mendelsohn, 1969)._The empirical research for the study was conducted in Denver in 1966, a city which at the time of the books completion (1968), had 'been spared the full fury of urban discontent' (Bayley \& Mendelsohn, 1969: v). Nevertheless, this was an important book and in a | contemporary review published in the American Journal of Sociology it was assessed to be, 'one of the most comprehensive studies of police-community relations ever undertaken'. 'The book, which sought to explore empirically, 'the texture of relations between the police and community, 
especially minority groups' was also timely. As the authors state in their introduction, 'in the welter of emotion that surrounds this subject, facts are at a premium' (Bayley \& Mendelsohn, 1969: iii)._Although their data were_gathered from only one city,_they_suggested that their findings were likely to be applicable to other American cities, with the proviso that, 'it will remain for other scholars in other cities to determine whether our hypotheses are in fact generalizable'. This quote,_betrays David's_natural science methodological influences mentioned earlier and is also typical of his career long cautious approach to social science scholarship. Also | characteristically,_Minorities and the Police_concludes with specific points underscoring the 'lessons learned' from the study about improving police and minority community relations.

Indeed, as I write this essay (U.S.A., December 2014) the American news media is dominated by the reporting of recent_events in Staten Island, New York as well as Ferguson, Missouri,_where two African-American citizens have died following encounters with the police. Following the associated civil unrest in Ferguson, in particular, some commentators have drawn parallels with the events of the 1960s. Whilst this may transpire to be_an exaggeration, it does seem that American law enforcement has entered a new period of crisis. Once again, there is_a welter of emotion surrounding the subject of relations between minorities and the police and many hold strong opinions on how things need to change. It seems like a suitable time to revisit an empirically informed book, written over four decades ago, in which the authors write on the penultimate page:

Talk is cheap, however, and so it has an immediate appeal. Educators and scholars seem particularly fond of it. If our analysis of the roots of police minority hostility is correct, it is exceeding doubtful whether talk alone can solve the problem. Social reform may be assisted by talking, but talk alone cannot substitute for social reform (Bayley \& Mendelsohn 1969: 205).

\section{Comparative and community policing specialist}

David would remain at the University of Denver until 1985. In this productive period he continued to teach and to research and publish articles in political science and foreign affairs journals on a range of topics. It was becoming clear, however, that he was specializing in law enforcement related research. In the period between 1969 and 1985 his research was published in policing related journals and he also wrote two major books. 
It has already been noted that there are a number of recurring themes in David's scholarship, however, if it is the duty of an author writing an essay such as this to identify an overarching theme in their subject's scholarly career then in David's case one such theme stands out. Whilst ideas and concepts_such as:-_democratic policing, human rights, community policing, police accountability and_reform are important in their own right, for David they coalesce around his career long intellectual project to explore the central question_of how societies cope with establishing a balance between freedoms and the maintenance of a stable order. Consequently, in this period of his career it is the public police whom_he regards as being central to this enquiry and therefore a primary focus for his_international comparative_research for which he became so well known.

An early and masterful example of this comparative approach can be found in an essay entitled, The Police \& Political Development in Europe_(Bayley, 1975). In this work David returns to the theme of exploring the relationship between the police and political development, but this time focussing on the period when recognisably modern police agencies_were forming in European states (approximately 1660 to 1888). Through this perspective David explains why the contemporary police systems of Great Britain, France, Germany, and Italy have assumed the forms they have. The essay is required reading for anyone who wishes to understand the development of professional policing in historical and comparative context, not least as it negates the commonly held view that modern forms of policing were fashioned in London, England in 1829.

His next major publication,_Forces of Order: Police Behaviour in Japan and the United States (Bayley, 1976)_was based on pioneering field research which he conducted in Japan in the early 1970's.The study grew from David's 'attempt to learn about the police problems of the United States by studying Japanese police institutions' (1976: ix). Although there are sections in the book which deal with issues of social unrest and the policing of violent protests, the main focus of this influential study centres on Japan's home-grown approach to neighbourhood policing. The book describes Japan's unique and extensive system of small police substations, known as 'koban's, which are staffed by a small team of officers who conduct regular foot or bicycle patrols, as well as visits to homes and businesses in the neighbourhood. He argued that the Japanese approach successfully integrates the police into the community, producing a longterm payoff in police community relations and crime prevention and detection. Whilst drawing 
some important parallels between the societies of Japan and America and their approaches to policing, he was characteristically_cautious about whether Japanese practices can be effectively imported to his home country. As David argued, 'police practices are not interchangeable parts,' as all of them are unlikely to 'fit a different social context' (1976:195-98)._However, as Steinhoff (1993: 834) observed, 'the book sparked broad professional interest in Japanese methods of policing and played a significant role in the community policing movement, prompting some quite successful American experiments with urban foot patrols and neighbourhood police substations'.

As the community-oriented policing movement spread to numerous other industrial democracies_around the world, David would become one of the key scholars associated with researching and_promoting (and critiquing) this policing strategy. This was achieved through key publications such as:- Community Policing: Issues and Practices Around the World (Bayley \& Skolnick 1988).

\section{Patterns of policing}

| By the mid-1980s, from his international studies base_camp at the University of Denver, David had established himself as a world-class international policing scholar and leading authority on American law enforcement. In addition to the studies and publications already discussed, he was engaged in the related research themes of police_reform (Bayley, 1977) and innovation_(Bayley \& Skolnick, 1986).

In 1985, however, David left Denver to take up a position as professor in the School of Criminal Justice Studies at the State University of New York (SUNY). This move also coincided with the publication of another important book: Patterns of Policing: A Comparative | International Analysis (Bayley, 1985),_which cemented his reputation as the world's preeminent practitioner of comparative policing studies. As McLaughlin (1992: 622) argued when he reviewed the paperback edition of Patterns (published in 1990), '...his book seems destined to remain the yardstick against which other books on comparative policing will be judged. In 1990 David's work was also the subject of an insightful essay by Dilip Das, who reviewed his key policing publications up to that point (Das, 1990). Das suitably describes Patterns as, 'a "gigantic thinkpiece" that reflects the state of knowledge about police development in many countries' (1990: 216). In the preface_David explained that he was motivated to undertake the study because, 'no scholars or practitioners were making systematic attempts to analyze police 
developments internationally' (1985: xi). The book 'represent[ed] the culmination of almost twenty years of personal research on national police institutions' (1985: xi).

Although_in this book David_was predominantly concerned with comparing contemporary_public_policing agencies he also discussed the_re-surgence and growth of private forms of policing, another topic which seemingly_few other scholars appreciated the significance of at that time (although see, for example, Stenning \& Shearing, 1980; Shearing \& Stenning, 1981, 1983). As we will see, the examination of non-state forms of policing would subsequently become another signature theme in David's scholarship and he and a handful of other scholars would produce a cannon of work which some commentators regard as marking nothing less than a paradigm shift in the study of policing and security.

Prior to this, however, in 1994,_David published another major book on the public police. Police for the Future (Bayley, 1994) is a 'tour de force' (Skogan, 1996:100) which explores what is wrong with public police agencies and how they may be made more effective._Naturally, his approach was international and comparative and it was based on four years of intensive research in five democratic countries- Australia, Great Britain, Canada, Japan, and the United States. In this book David exposed, 'one of the best kept secrets of modern life', namely that 'the | police do not prevent crime'. As he wrote_in his characteristically lucid and jargon free style, '...the police pretend that they are society's best defense against crime and continually argue that if they are given more resources, especially personnel, they will be able to protect communities against crime. This is a myth' (Bayley, 1994: 3)._In the final section, 'a blueprint for the future', David endorsed a radical 'three tiered' model of community policing_involving decentralisation and accountability to the public and calls for the conventional police hierarchy to be 'stood on its head'._As Skogan (1996:101) concluded in his review of the book:

Unlike many hortatory conclusions to_books, his detailed program flows directly_from his analysis of the predicament that_policing finds itself in, and in many ways finds_its roots in social research. This is a_wonderful and wise book that should have_wide impact.

\section{The future of policing}

Yet ironically in terms of David's reputation, if there was a limitation in his approach to Police for the Future it was that he had, according to Leishman, (1996: 536) 'overstate[d] the public police's "monopoly" over crime prevention, given the diverse sectoral and spatial mix of | policing already in existence...'._As already signalled, at least a decade previously David had 
been one of the first scholars to begin to explore and draw attention to these developments. By the early-1990s a 'quiet revolution' was underway in criminological scholarship and the field had been advanced and expanded, particularly through the pioneering work of Philip Stenning and Clifford Shearing (1980, 1981, 1983,) (see Wood, 2014:522). This body of work helped to shift 'private security from the margins to the centre of theoretical analysis' (McLaughlin, 2007: 90) and led to a 'critical conceptual move from police work to policing' (Wood, 2014: 522). In 1996_the quiet revolution got_louder following David's collaboration with Clifford Shearing on a radical and influential article: The Future of Policing (Bayley \& Shearing, 1996). David explained how his collaboration with Professor Shearing arose:

Clifford and I were both working independently on the theme of different forms of policing.

He was conducting empirical research into private policing in Canada and I came at the topic via a different route through my interest in social order. It came to me that it was not just the public police that were holding things together; there were other institutions which were helping processes of socialization; although of course this was not something I invented as it came out of sociology. But Clifford and I realised that we were touching the same elephant and we just fell into each other's arms.

In The Future of Policing Bayley and Shearing argued that policing systems in developed democratic societies were undergoing radical change. The article begins with what has become one of the most quoted statements in the_policing studies literature:

Modern democratic countries like the United States, Britain, and Canada have reached a watershed in the evolution in their systems of crime control and law enforcement. Future generations will look back on our era when one system of crime control ended and another took its place (Bayley \& Shearing, 1996: 585).

Their thesis rested on two elements:_first, that the period since the mid-1960s has seen the 'end of the monopoly' by the public police and the emergence of a 'pluralized' system of security provision, and second, that the public police are going through an 'identity crisis'._In 2001, Bayley and Shearing developed their thesis in a publication sponsored by the U.S Department of Justice entitled,_The New Structure of Policing: Description, Conceptualization and Research Agenda, (Bayley \& Shearing, 2001). In this work they coined the term 'multilateralization' to_describe recent developments. As they argued:

Policing today is not just being "privatized." It is being restructured though the development of new groups as both instigators and providers of policing. The public and the private are 
being combined in new ways, ways that sometimes make it difficult to separate public from private. Multilateralization, although an awkward term, is a more accurate way of describing what is happening to policing in the late 20th century than privatization (2001:15).

\section{International policing expert}

Since arriving at SUNY the extent and range of his domestic and international policing research and consultation work had snowballed._His U.S based consultation_work included projects for the_Police Foundation, the Police Executive Research Forum (PERF), the Harvard Second Executive Session on the Police, as well as the U.S Department of Justice. More internationally, he was involved in consultation projects for the United Nations, the United States Institute of

Peace, as well as numerous governments and police agencies abroad,_including in Canada, Singapore, Australia and the United Kingdom.

\section{Policing, democracy and reform}

One of his most influential internationally focussed research projects was sponsored by the U.S National Institute of Justice (NIJ). In 1999 David was awarded a research grant by the NIJ to research and document what was known about how to reform police forces abroad so as to support the development of democracy. The need to provide practical advice to American reformers had arisen because assistance to foreign police had increased significantly since the end of the Cold War, and there were three main precipitators for the project (Bayley, 2001). First, during the 1990s democratic reform of foreign police systems had become a 'front-burner issue in American foreign policy' (2001:5) and significant numbers of U.S law enforcement personnel were being deployed in missions across many parts of the world. Second, there had been a parallel growth in the number and nature of multinational interventions_in policing and, by 2000 , the United Nations had deployed 9,000_civilian police from 34 nations. Thirdly, the U.S government had become increasingly concerned about the rise of transnational crime.

Although by the late 1990s there were several other distinguished scholars who were researching and writing about the idea of democratic policing (e.g. Jones, Newburn \& Smith, 1996), Professor Bayley was an obvious candidate to lead on the NIJ project._After all, it has already been noted that_in his 1969 book on India David had outlined how the police could shape political development,_so in many respects he was now building on research themes he had started to explore some three decades earlier._As Manning (2008:7) writes in his own excellent 
book on Democratic Policing, in which he begins by reviewing the work of key scholars who have grappled with the topic:

Thirty-two years later the most dramatic, well-written, and well-presented argument concerning the requirements for democratic policing is again David Bayley's. It is found in a U.S Department of Justice Publication (Bayley and National Institute of Justice 2001and later in a revised form in a book, Changing the Guard (2006).

These requirements include David's now classic statement of the principles democratic policing. By which the police organisation should: [this needs a source citation, page number]

- 'Give top operational priority to serving the needs_of individual citizens and private groups.

- Be accountable to the law rather than to government.

- Protect human rights, especially those involving unfettered political activity, which is the hallmark of a democracy.

- Be transparent in its activity' (Bayley, 2001: 13-14).

Since Changing the Guard_David has continued to research and publish on the related themes of democratic policing (Bayley, 2009); foreign policy, peacekeeping and the role of the | police in zones_of conflict (Bayley \& Perito, 2010), counter terrorism (Bayley \& Weisburd, 2009), police corruption (Bayley \& Perito, 2011), and police reform (Bayley, 2008).

In Police reform: Who done it?_(Bayley, 2008)_David examined the provenance of the main innovations in American policing which had occurred since the mid-1960s._His aim in the paper was to establish where the 'big reform ideas in policing [had] come from', and more specifically whether or not the innovations had been 'self-generated' by police organizations, including by the 'rank-and-file' (2008:7). Despite having spent so many years researching policing, his findings 'surprised' even him. He concluded that,_the United States has been the source of most of the big new ideas in policing in the past half century'. This occurred_under what he termed a 'top-down' and inside-outside' paradigm, in which the key reforms were 'instigated by people, or events, outside the police themselves'. Yet, whereas some commentators might be_tempted to criticise police leaders for their apparent lack of creativity, David's standpoint in the paper was typically a model of balance and a demonstration of his own original way of looking at things. Whilst he argued that it was 'regrettable' that rank-and-file officers had not been the source of significant reforms ideas, he regarded it as a 'cause for celebration' that the key reforms had been instigated by 'outsiders' who had now become part of the American 'police establishment'. As he concluded: 
The American reform paradigm constitutes a new and generally unrecognized_mode of public accountability. It has allowed America's intellectual elite to monitor_policing by becoming 'embedded' in police departments. This is remarkable when_you consider that the norm in the rest of the world is for professional intellectuals to_be hostile to the police (2008: $15)$.

Having also spent more than half a decade in academia David followed up on his 2008 article on police reform with his2011 paper:_Ettu brute: are police agencies managed better or worse than universities?_(Bayley, 2011)._In this publication he systematically compares and critiques police organisations and universities, finding many similarities between policing and his own profession. As he argued, 'in several respects universities, American ones at least, may be even less rational than the police, despite their pretentions to intellectual superiority, rationality and selfless service'. Characteristically, the paper was witty and according to the Journal Editors it was 'meant to amuse' (Cordner \& Shain, 2011:283). Yet when I spoke to David about the article he made it clear that he meant every carefully chosen word: 'I just had to get this off my chest. Academics talk about how the police need to change, but guys, have you thought about where you are working. Give us a break'. As Cordner and Shain (2011:283) concluded, " the paper can be taken as a word of caution for those police reformers who might idealistically believe that higher education has all the answers for the problems of the police'.

Although David retired from SUNY in 2010, he remains, at the age of 82, as busy and productive as ever and he is currently collaborating on a comparative study of the relations between senior police officers and elected officials in democracies._David continues to hold several consultative positions and he remains in great demand as a speaker at international conferences and as an adviser to law enforcement and government agencies around the world.

\section{Concluding remarks}

It has not been difficult a task to make the case for Professor Bayley being a pioneer of policing research and the world's leading internationalist policing scholar. The facts of his six decade | career and his extensive publications across a range of interrelated important macro-level topics in policing studies speak for themselves. The main challenge, however, in a short essay such as this, is to do justice to the range of his professional achievements as well as the personal qualities which make Professor Bayley so unique. Two further aspects of David's working personality remain to be acknowledged briefly. 


\section{A real-life Indiana Jones}

First, having placed significant emphasis on his research and publications, we must not forget that Professor Bayley is also a_pioneering teacher and research advisor. He has played an instrumental role in the advanced education and academic training of a generation of criminal justice scholars, many of whom have gone on to become distinguished academics in the field. | His former students include Professor Robin S. Engel,_(University of Cincinnati), Professor Steve Chermak (Michigan State University) and Professor Ed Maguire, (American University), and I am grateful to all three for their contributions here.

Robin Engel explained how David pioneered the provision courses at SUNY which brought together practitioners from law enforcement agencies in the U.S.A and around the world with would-be American criminal justice scholars. ${ }^{5}$ As Robin told me, 'as a professor, David was masterful at interweaving the seasoned practitioners' practical concerns with the young budding academics' larger theoretical concepts'. Robin's formative interactions with David were so instrumental in her doctoral education that she went on to emulate his approach with the | establishment of_successful practitioner/academic collaboration projects at the University of Cincinnati (see, for example, Engel \& Whalen, 2010).

Steve Chermak is the most recent recipient of the ACJS prestigious Bruce Smith Sr. | Award, which_David also received in 2003. Steve regards David as 'one of the most influential and important people in [his] life' and he attributes much of his own success to the mentorship | he received from him early on in his academic career._As Steve explains:

David influenced my career dramatically when he strongly suggested that I take my dissertation project to the field - "get your hands dirty" - and bring a critical eye to what you can observe about your subject matter. It may be the single best advice I have gotten (and now give) ${ }^{6}$

Ed Maguire was a doctoral student at SUNY in the mid-1990s._Ed explained that_as a 'blue-collar kid and a first generation college student', he was 'struck by David's worldliness' and he seemed to him like a 'real-life Indiana Jones'?

\section{The X Factor}

The final aspect of David's working personality which remains to be acknowledged are qualities which cannot be_directly taught on any $\mathrm{PhD}$ programme. These are the qualities which have contributed so much to his impressive career and are the qualities which are immediately 
apparent to anyone who has any dealings with him. In researching and writing this essay I have consulted with numerous people who have either worked with David or studied under him, and without exception everyone has said the same: that despite his achievements and status, he is modest, generous with his time, and he is a 'great guy'. Having been fortunate to spend time with David to research this essay I can testify to this. Nowadays, there are many academics who are attempting to research the police, but it takes a special kind of social scientist to get my policing colleagues to open up in ways which David does. As Robin Engel explains:

David always has this amazing way to connect people professionally and personally - with a twinkle in his eye, he makes everyone feel comfortable and engaged. It is little wonder that he could do so much extraordinary work in foreign lands. Most academics cannot get established working with police agencies in their own hometown, let alone all around the world. But David just has this way with people - and as a result, his ideas were tried and embraced by police agencies all around the world - and that is very rare indeed. ${ }^{8}$

There are also many political scientists and policing scholars who can write analytically and well about concepts such as democracy, freedom, power and conflict, but there are few who approach them through deeply held and morally principled personal beliefs._It is no coincidence that it was David who produced '...the most dramatic, well-written, and well-presented argument concerning the requirements for democratic policing' (Manning 2008:7). He did so because democracy is something he believes in, and he has brought this_conviction to all the_important macro-level topics and issues in policing studies he has chosen to focus on throughout his career. I leave the final words to Ed Maguire, who is better able to succinctly sum up David's | contribution than I:_the policing field is full of people staring at the trees. For nearly six decades, David has defined what it means to look at the forests'.

\section{Notes}

| ${ }^{1}$ Excerpt from President Truman's address to the opening session of United Nations Conference on International Organisation (20/4/1945). U.S Department of State Bulletin. Available at. http://www.ibiblio.org/pha/policy/1945/450425a.html Retrieved 20/2/2015

| ${ }^{2}$ U.S Department of State: Office of the Historian. Available at https://history.state.gov/milestones/19371945/american-isolationism . Retrieved 20/2/2015

$\mid{ }^{3}$ Interview with David H. Bayley. Hereafter in this paper, any unreferenced quotations are derived from interviews and personal correspondence with Professor Bayley.

${ }^{4}$ Quotation taken from rear cover of paperback edition published 1971. New York: The Free Press.

${ }^{5}$ Personal correspondence with Professor Robin S. Engel. 
${ }^{6}$ Personal correspondence with Professor Steve Chermak.

${ }^{7}$ Personal correspondence with Professor Ed Maguire.

${ }^{8}$ Personal correspondence with Professor Robin S. Engel.

${ }^{9}$ Personal correspondence with Professor Ed Maguire.

* Notes on contributor and acknowledgements

| Dr Richard Heslop is a Sergeant in West Yorkshire Police, England. He is a Fulbright Scholar and in 2014 he was a Visiting Professor at the John Jay College of Criminal Justice, U.S.A, where he was given the opportunity to research this essay. The author also wishes to acknowledge invaluable help from: Robin Engel, Ed Maguire, Steve, Chermak, Otwin Marenin, Dilip K. Das and, of course, Distinguished Professor David H. Bayley. Sergeant Heslop can be reached at r.heslop@ fulbrightmail.org

\section{References}

Banton, M. (1964). The Policeman in the Community. London: Tavistock.

Bayley, D. H. (1962). Preventative Detention in India. Calcutta: K.L Mukhopadhyay.

Bayley, D. H. (1964). Public Liberties in the New States. Chicago: Rand McNally \& Co.

Bayley, D. H. (1969). The Police and Political Development in India. New York: The Free Press.

Bayley, D.H. (1975). The Police and Political Development in Europe. In Tilly, C. (Ed), The Formation of National States in Europe. Princeton: Princeton University Press.

Bayley, D.H. (1976). Forces of Order: Police Behaviour in Japan and the United States. Berkley: University of California Press.

Bayley, D. H. (1985). Patterns of Policing. New Brunswick: Rutgers University Press.

Bayley, D.H. (1989). A Model of Community Policing: The Singapore Story. Washington, D.C: National Institute of Justice.

Bayley, D.H. (1994). Police for the Future. New York: Oxford University Press.

Bayley, D.H. (1995). A Foreign Policy for Democratic Policing. Policing \& Society, 5 79-93.

Bayley, D.H. (1999). Policing: the World Stage. In Mawby, R, I. (Ed), Policing Across the World: Issues for the Twenty-first Century. London: Routledge.

Bayley, D.H. (2001). Democratizing the Police Abroad: What to Do and How to Do it. Washington, D.C: National Institute of Justice.

Bayley, D.H. (2006). Changing the Guard: Developing Democratic Police Abroad. New York: Oxford University Press.

Formatted: Font: 12 pt, Italian (Italy)

Formatted: Italian (Italy) 
Bayley, D.H. (2008). Police Reform: Who Done It? Policing \& Society, 18:1, 7-17.

Bayley, D.H. (2009). Democratic Policing. In Wakefield, A. \&Flemming, J. (Eds), The Sage Dictionary of Policing. Thousand Oaks, CA: Sage.

Bayley, D.H. (2011). Ettu brute: are police agencies managed better or worse than universities?". Police Practice \& Research: An International Journal, 12:4: 313-316.

Bayley, D. H. \& Mendelsohn, H., (1969). Minorities and the Police: Confrontation in America. New York: The Free Press.

Bayley, D.H. \& Skolnick, J.R. (1988). Community Policing: Issues and Practices Around The World. Washington D.C: National Institute of Justice.

Bayley, D.H. \& Perito, R. (2010).The Police in War: Fighting Insurgency, Terrorism and Violent Crime. Boulder: Lynne Rienner Publishers.

Bayley, D. H. \& Perito, R. (2011). Police Corruption: What Past Scandals Tell Us About Future Challenges. Washington DC: Institute for Peace.

Bayley, D.H \& Shearing, C. (1996). The Future of Policing. Law \& Society Review. 30:3, 585606.

Bayley, D.H \& Shearing, C. (2001). The New Structure of Policing: Description, Conceptualization and Research Agenda. Washington, DC: National Institute of Justice.

Bayley, D.H \& Weisburd, D. (2009). Cops and Spooks: The Role of the Police in Counter Terrorism. In Weisburd, D. et.al (Eds),To Protect and Serve: Policing in an Age of Terrorism and Beyond. New York: Springer.

Bowling, B., \& Sheptycki, J. (2014). Robert Reiner: a pioneer in policing scholarship. Police research pioneer. Police Practice \& Research: An International Journal, Published on line, 12 May 2014.

Cordner, G., \& Shain, C. (2011). Editorial: The changing landscape of police education and training. Police Practice \& Research: An International Journal, 12: 4, 281-285.

\footnotetext{
Das, D. K. (1990). Review Essay: The Work of David. H. Bayley. Justice Quarterly, 7:1, 209$\underline{225}$.
}

Engel, R. S, \& Whalen, J.L (2010). Police-academic partnerships: ending the dialogue of the deaf, the Cincinnati experience. Police Practice \& Research: An International Journal. $11: 2,105-116$. 
Flamm, M, W. (2007). Street Crime, Civil Unrest, and the Crises of Liberalism in the 1960s. New York: Columbia University Press.

Heslop, R. (2012). A Sociological Imagination: Simon Holdaway, police research pioneer. Police Practice \& Research: An International Journal, 13:6, 525-538.

Jones, T., Newburn, T., \& Smith, D, J. (1996). Policing and the Idea of Democracy. The British Journal of Criminology, 36:2, 182-198.

Leishman, F. (1996). Review of Police for the Future. American Journal of Sociology, 101: 2, 534-536.

Manning, P, K. (2008). Democratic Policing in a Changing World. Boulder: Paradigm

McLaughlin, E. (1992). Review of Patterns of Policing: A Comparative International Analysis. The Sociological Review, 40:3, 618-622.

McLaughlin, E. (2007). The New Policing. London: Sage.

Shearing, C., \& Stenning, P. (1981). Modern private security: Its growth and implications. In M.Tonry\& N. Morris (Eds.), Crime and justice: An annual review of research, 96-110. Chicago, IL: The University of Chicago Press.

Shearing, C., \& Stenning, P. (1983). Private security: Implications for social control. Social problems, 30, 493-506.

Skogan, W, G. (1996) Review of Police for the Future. Contemporary Sociology. 25:1, 100-101.

Skolnick, J. (1966). Justice Without Trial: Law Enforcement in a Democratic Society. New York: Wiley.

Steinhoff, P, G. (1993) Pursuing the Japanese Police. Law \& Society Review, 27:4, 827-850.

Stenning, P., \& Shearing, C. (1980). The quiet revolution: The nature, development and general legal implications of private security in Canada. Criminal Law Quarterly, 22, 220-248.

Wood, J, D. (2014). Pioneers in policing: Clifford Shearing. Police Practice \& Research: An International Journal, 15:6, 519-532. 